\title{
The association of housing conditions with wheezing in children up to 36 month- old: an observational study in Arco Ribeirinho region
}

\author{
Associação das características da habitação com episódios de sibilância em bebés até 36 \\ meses: estudo observacional na região do Arco Ribeirinho
}

\author{
Raquel Rodrigues dos Santos ${ }^{1,2}$, João Gregório ${ }^{1}$, Liliana Castanheira ${ }^{1,3}$, Ana Fernandes ${ }^{1}$ \\ ${ }^{1}$ CBIOS - Research Center for Biosciences and Health Technologies \\ ${ }^{2}$ Administração Regional de Saúde de Lisboa e Vale do Tejo, Agrupamento de Centros de Saúde do Arco Ribeirinho, \\ Unidade de Saúde Pública Arnaldo Sampaio \\ ${ }^{3}$ Administração Regional de Saúde de Lisboa e Vale do Tejo, I.P., Centro Hospitalar Lisboa Ocidental, Unidade Saúde \\ Familiar do Dafundo \\ Email: joao.gregorio@ulusofona.pt
}

\begin{abstract}
Infant mortality due to respiratory disease is a major cause of concern for global health. The prevalence of asthma and other respiratory diseases in early childhood is still high, overburdening health care services and systems. Housing conditions where early infancy is spent has been associated with the incidence of respiratory diseases. The aim of this study was to investigate the possible association between housing characteristics and the occurrence of wheezing episodes in children under 36 months of age. A cross-sectional study was performed on a sample of children under 36 months of age in Arco Ribeirinho region. 131 participants were selected through the children consultation services. Most lived in apartments in an urban setting. There was no association between wheezing and the type of housing (house vs. apartment) nor with the area (urban vs. rural). However, it was found that room area has an influence on the occurrence of wheezing episodes: smaller rooms tend to present babies with more incidences of episodes. In future investigations, it will be important to explore the causes of this association, namely the contribution that some indoor air pollutants may have to wheezing and respiratory disease in infants.
\end{abstract}

Keywords: Infant respiratory disease; Wheezing; Housing; Indoor air quality

\section{Resumo}

A prevalência de doenças respiratórias na primeira infância é ainda elevada, sobrecarregando os serviços e sistemas de saúde. As condições da habitação onde se vive a primeira infância têm sido associadas à incidência das doenças respiratórias. O objetivo deste estudo foi averiguar a possível associação entre características das habitações com a ocorrência de episódios de sibilância em crianças com menos de 36 meses de idade. Foi desenhado um estudo transversal numa amostra de bebés na região do Arco Ribeirinho. Foram selecionados 131 participantes através da consulta de Saúde infantil. A maioria vivia em apartamentos num ambiente urbano. Não se verificou qualquer associação entre sibilância e o tipo de habitação (casa vs. apartamento) nem com a zona (urbana vs. rural). No entanto, verificou-se que a área do quarto tem influência na ocorrência de episódios de sibilância: quartos mais pequenos têm tendência a apresentar bebés com mais incidência de episódios. Em futuras investigações, será importante averiguar as causas desta associação, nomeadamente o contributo que alguns poluentes do ar interior podem ter para o surgimento de sibilância e doença respiratória em bebés.

Palavras-chave: Doença respiratória infantil; Sibilância; Habitação; Qualidade do ar interior 


\section{Introdution}

Prevalence of respiratory disease in early childhood is a major cause of concern for global health (1). It is estimated that every year more than 900 million children under 5 years of age die of pneumonia worldwide and at least 3 million die due to environment-related diseases $(1,2)$.

The prevalence of wheezing, a symptom associated with asthma in small children, has also been rising around the globe, influencing quality of life and impacting health system costs (3). Wheezing is identified as a non-specific respiratory signal, audible with or without a stethoscope (4). Due to its association with respiratory disease, wheezing is usually used as a proxy outcome to study the effect of exposure to air pollutants and living conditions on the incidence of respiratory diseases (5). The reasons for this prevalence are complex and involve an intricate interaction of several factors, such as living conditions, housing quality, or indoor air pollutants exposure $(6,7)$. From location, basic structure and quality of materials, housing is one of the most relevant social determinants of health affecting newborns' health status (8). As babies spend most of their time indoors, indoor air quality (IAQ) has received some attention from researchers (9). Among several factors influencing IAQ, tobacco smoke as well as other household chemical compounds have been associated with respiratory disease prevalence in infants (6). Moreover, the presence of moulds and dampness is also associated with respiratory disease (10).

The scarce evidence about the effect of housing conditions on the respiratory health of newborns in highincome countries, shows that people with lower standards of living are more affected (11). Until now, studies about the effect of indoor air pollutants on children's respiratory health in Portugal have been focused on school-aged children and school environments (12). Thus, it is important to assess how housing conditions may influence the incidence of respiratory disease in newborns. Considering this, the aim of this study was to assess the association between several housing characteristics and the presence of wheezing in children under 36 months of age.

\section{Introdução}

A prevalência de doenças respiratórias na primeira infância tem sido uma das principais preocupações para a Saúde global (1). Em todo o mundo, estima-se que mais de 900 milhões de crianças com menos de 5 anos morram de pneumonia e que pelo menos 3 milhões morram por doenças relacionadas com o meio ambiente num só ano $(1,2)$.

A prevalência de sibilância, um sintoma associado à asma em crianças, também tem aumentado em todo o mundo, influenciando a qualidade de vida e contribuindo para o aumento dos custos dos sistemas de saúde (3). A Sibilância é identificada como um sinal respiratório não específico, audível com ou sem estetoscópio. De forma corrente, utilizam-se termos como "apito no peito" ou "pieira" (4). Devido à sua associação com doença respiratória, a sibilância é geralmente usada como um sinal para auxiliar o estudo do efeito da exposição a poluentes do ar e condições de vida na incidência de doenças respiratórias (5).

As razões para esta alta prevalência são complexas e envolvem uma intrincada interação de vários fatores, como condições de vida, qualidade da habitação ou exposição a poluentes do ar em ambientes fechados(6,7). Desde a localização, à estrutura básica e qualidade dos materiais, a habitação é um dos determinantes sociais de saúde mais relevantes para o estado de saúde dos recém-nascidos (8). Como os bebés passam a maior parte do tempo dentro de casa, a qualidade do ar interior (QAI) tem recebido alguma atenção dos investigadores (9). Entre vários fatores que influenciam a QAI, o fumo do tabaco e outros compostos químicos utilizados na habitação têm sido associados à prevalência de doenças respiratórias em bebés (6). Além disso, a presença de fungos e humidade também está associada à doença respiratória (10).

A pouca evidência existente sobre o efeito das condições da habitação na saúde respiratória de recém-nascidos em países de altos rendimentos, aponta para uma associação com a pobreza e baixa qualidade de habitação (11). Até agora, os estudos sobre o efeito de poluentes do ar interior na saúde respiratória de crianças em Portugal têm sido focados no efeito das condições ambientais das escolas (12)Portugal. In a case-control study (30 case children with asthma and 38 controls. Assim, é relevante avaliar como as características da habitação podem influenciar a incidência de doenças respiratórias. Tendo isto em consideração, o objetivo deste estudo foi estudar a associação entre várias características da casa e a presença de sibilância em crianças com menos de 36 meses de idade. 


\section{Methods}

A cross-sectional study was designed to determine the prevalence of wheezing and its association to housing characteristics of newborn population in the Arco Ribeirinho region. A total of 6151 babies were born in this region from 2012 through 2014. The sample size for a $95 \%$ confidence interval was determined to be 362 . The sample was recruited by convenience, in the children consultation services consultations at the region's 13 health units. Recruitment lasted from July to September 2015, yielding a total of 269 subjects. Data collection took place from October 2015 through March 2016.

Temperature $\left({ }^{\circ} \mathrm{C}\right)$ and relative humidity $(\%)$ were measured using a $3 \mathrm{M}$ Quest ${ }^{\mathbb{R}}$ EVM-7 environmental monitor. A survey was applied in order to study housing characteristics and room features, as well as to verify the occurrence of wheezing episodes (13). Among the characteristics of interest were housing typology, urban or rural area, floor location of babies' rooms, room size, frequency of window opening, and the presence of visible moulds.

All statistical analyses were performed in IBM program Statistical Package for Social Sciences (SPSS) version 23. The Shapiro-Wilk test was used to assess normality of continuous variables, the Student's t-test? For independent samples, and Mann-Whitney and KruskalWallis tests were used to assess mean and median differences. Qui-square test was used to assess associations between categorical variables. Binary and multinomial logistic regressions were performed to assess the association of explanatory variables with the presence of wheezing. The significance level was set to $\mathrm{p}<0.05$.

Approval from Lusófona University and Tagus Valley Health Administration Ethics committees was obtained prior to any research activities (License $n^{\circ} .4 / 2015$ and 11386/CES/2015 respectively).

\section{Results and Discussion}

From the initial 269 families with babies that showed interests in participating, only 131 took part in the data collection stage, representing $36 \%$ of the original targeted sample size. Although this is an acceptable number of participants when compared with similar studies, caution should be taken when interpreting the results

\section{Métodos}

Para estudar a associação das características habitacionais com a prevalência de sibilância numa a população de recém-nascidos, foi desenhado um estudo transversal para implementar na região do Arco Ribeirinho. Entre 2012 e 2014 nasceram nesta região um total de 6151 bebés. O tamanho da amostra para um nível de confiança de $95 \%$ foi calculado em 362. A amostra foi recrutada por conveniência, nas consultas de Saúde Infantil nas 13 Unidades Funcionais do Agrupamento de Centros de saúde da região. O recrutamento durou de julho a setembro de 2015, com 269 famílias a aceitarem participar. O período de recolha de dados ocorreu de outubro de 2015 a março de 2016.

A temperatura $\left({ }^{\circ} \mathrm{C}\right)$ e humidade relativa $(\%)$ foram medidas usando o equipamento de medição ambiental 3M Quest ${ }^{\circledR}$ EVM-7. Foi desenvolvido e aplicado um questionário, com o intuito de estudar as características da casa e as características do quarto, bem como verificar a ocorrência de episódios de sibilância (13). Entre as características de interesse estavam o tipo de casa (moradia vs. apartamento), a localização da casa (urbana vs. rural), o piso onde se encontra e o tamanho do quarto, a frequência de abertura da janela e a presença de bolores visíveis.

Toda a análise estatística foi executada no programa IBM Statistical Package for Social Sciences (SPSS) versão 23. O teste de Shapiro-Wilk foi utilizado para verificar a normalidade das variáveis contínuas. O teste t-Student para amostras independentes, os testes de Mann-Whitney e Kruskal-Wallis foram utilizados para avaliar as diferenças de médias e medianas. O teste Qui-quadrado foi utilizado para avaliar associações entre variáveis categóricas. Foram feitas regressões logísticas binária e multivariada para avaliar a associação das variáveis de interesse com a presença de sibilância. O nível de significância foi definido para $\mathrm{p}<0,05$.

A aprovação pelos Comités de Ética da Universidade Lusófona e da Administração Regional de Saúde de Lisboa e do Vale do Tejo foi obtida antes de qualquer atividade de investigação (Licença $n^{\circ}$. 4/2015 e 11386 / CES / 2015, respetivamente).

\section{Resultados e Discussão}

A partir do contacto realizado com as 269 famílias com bebés, que inicialmente demonstraram interesse em participar, foi possível assegurar a participação de 131 na fase de recolha de dados, representando $36 \%$ da amostra original. Embora este seja um número aceitável de participantes quando comparado com estudos 
here presented, as we cannot assure that they are representative of the population.

The number of people living in the same house varied between 2 and 10, with most families (91.6\%) having between three and five people. $51.9 \%$ of the participant babies were boys. Babies' mean age was 11.60 months. Although boys were younger than girls, the difference was not significant. Table 1 presents the distribution of episodes of wheezing amongst the sample. Although more girls had episodes of wheezing, the difference was not significant. semelhantes, os resultados aqui relatados devem ser interpretados com cautela pois não é garantido que sejam representativos da população em estudo.

O número de pessoas que moram na mesma casa variou entre 2 e 10, com a maioria das famílias $(91,6 \%)$ tendo entre 3 e 5 pessoas. $51,9 \%$ dos bebés participantes eram meninos. A idade média dos bebés foi de 11,60 meses. Embora os meninos fossem mais jovens que as meninas, a diferença não foi significativa. A Tabela 1 apresenta a distribuição dos episódios de sibilância na amostra. Apesar de mais meninas terem episódios de sibilância, a diferença não foi significativa.

Table 1/ Tabela 1 - Prevalence of wheezing in the previous 12 months $(\mathrm{n}=131)$ / Prevalência de sibilância nos últimos 12 meses $(\mathrm{n}=131)$

\begin{tabular}{|c|c|c|c|c|c|c|c|}
\hline & \multicolumn{2}{|c|}{ Boys/Meninos } & \multicolumn{2}{|c|}{ Girls/Meninas } & & \multicolumn{2}{|c|}{ Total } \\
\hline Wheezing/Sibilância & $\mathrm{n}$ & $\%$ & $\mathrm{n}$ & $\%$ & $\begin{array}{c}\mathrm{p}- \\
\text { value }\end{array}$ & $\mathrm{n}$ & $\%$ \\
\hline Never/ Nunca & 49 & $72.1 \%$ & 37 & $58.7 \%$ & & 86 & $65.6 \%$ \\
\hline $\begin{array}{l}\text { Between } 1 \text { and } 3 \text { episodes/ Entre } 1 \text { e } \\
3 \text { episídios }\end{array}$ & 12 & $17.6 \%$ & 13 & $20.6 \%$ & 0.189 & 25 & $19.1 \%$ \\
\hline
\end{tabular}

\section{More than 3 episodes/ Mais de} 3 episódios
$20 \quad 15.3 \%$

\section{Total}

68
$10.3 \%$ 13

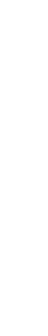


Table 2/ Tabela 2 - Housing and room characteristics $(\mathrm{n}=131) /$ Características da habitação e do quarto do bebé $(n=131)$

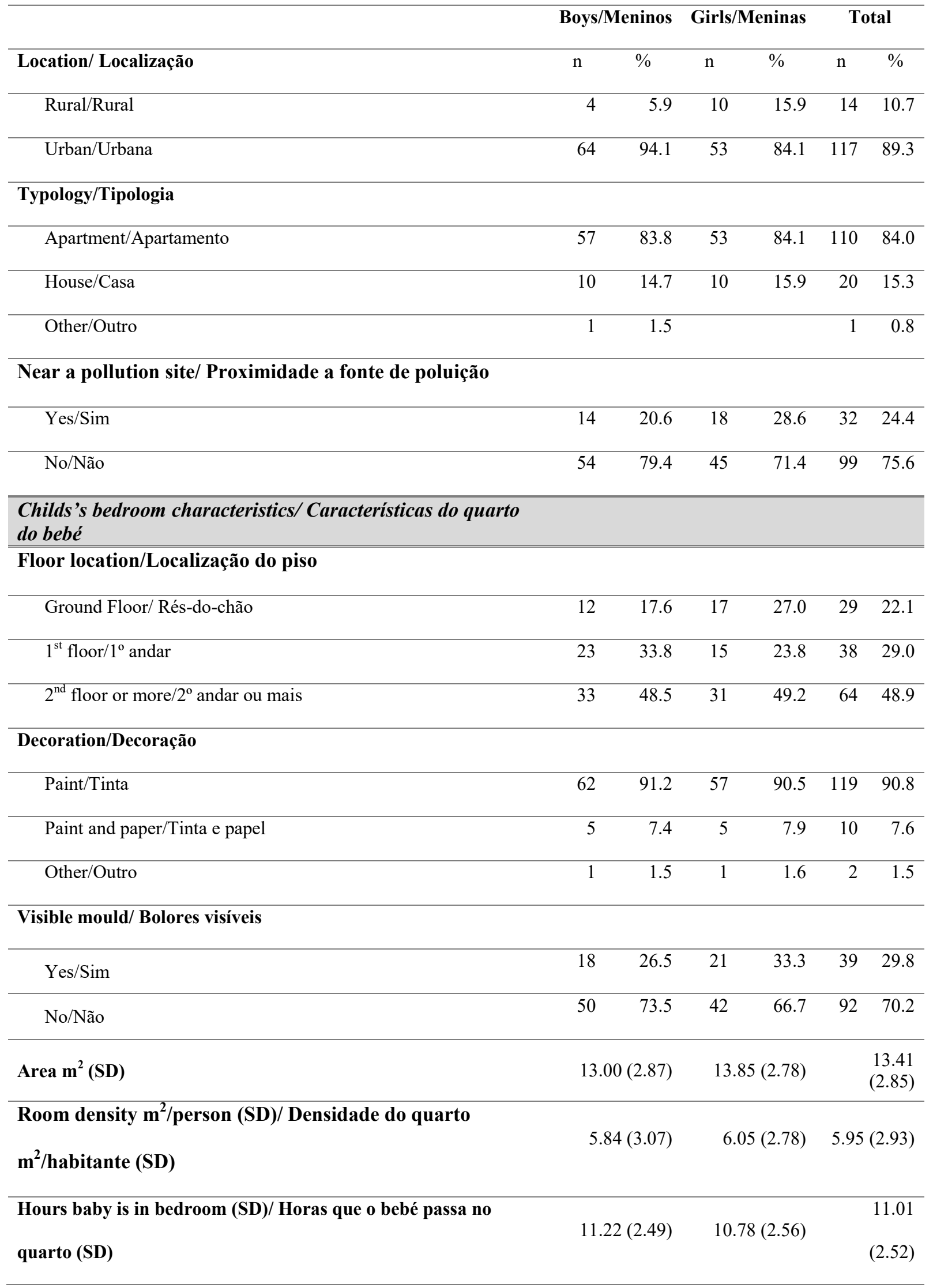


Most of our sample lived in an urban area apartment, with the child bedroom located at least in the first floor or higher. However, some respondents claimed to live in a rural area, reflecting the transition zone between city and rural environment typical of the region. The association between asthma and urban or rural settings has been reported in the literature $(14,15)$, but in this study, episodes of wheezing were not statistically associated with zone (rural vs. urban), the typology of building (apartment vs. house), nor with the floor level where the babies' rooms were located.

Only $24.6 \%$ of families lived near a pollution site, such as a highway, bus stop or gas station. This proximity has been reported as important for respiratory health since it has the potential to influence indoor air quality (16). However, in this sample no association was found between wheezing episodes and the proximity of a pollution site or the type of decoration used in the room.

In $29.8 \%$ of the bedrooms, the presence of moulds was visible. In spite of the known association between moulds and dampness with respiratory disease (10), moulds' presence in this sample was not associated with episodes of wheezing. Nevertheless, a significant association was found between the frequency of window opening and the presence of visible moulds $\left(\chi^{2} 5.700\right.$; $\mathrm{p}=0.017)$. The logistic regression model, adjusted for room size, relative humidity and temperature, showed that window opening frequency of less than once daily is associated with having visible moulds on the rooms' walls [aOR: 2.347 (CI 95\%:1.047-5.263); ( $\mathrm{p}=0.038)$ ]. Considering that moulds presence is usually associated with respiratory disease, this finding highlights the importance of promoting good practices of hygiene of indoor air through frequent renovation.

\section{Conclusion}

The research here reported allowed to study the possible association between babies' bedrooms characteristics and the occurrence of episodes of wheezing in the Arco Ribeirinho region. In spite of examining several room features, room size was the only feature to show a possible impact in the emergence of wheezing episodes: bigger rooms seem to prevent the occurrence of such episodes. In addition, this research contributes to highlight the importance of air renovation at least once a day to prevent the formation of moulds. de sibilância em 1.214x [(IC 95\%: 1.041 - 1.416); (p = 0,013)].

A maioria da amostra vivia num apartamento em área urbana, com o quarto do bebé localizado no mínimo no primeiro andar ou mais alto. Alguns participantes vivem numa área rural, refletindo a zona de transição entre cidade e meio rural típica da região. Neste estudo, os episódios de sibilância não foram estatisticamente associados à tipologia da habitação (apartamento vs. casa), ou zona (rural vs. urbana), nem com o piso onde os quartos dos bebés estavam localizados, apesar de outros terem estabelecido essa associação, especialmente entre asma o ambiente urbano ou rural $(14,15)$.

Apenas 24,6\% das famílias viviam perto de um local de poluição, como uma autoestrada, paragem de autocarro ou posto de gasolina. Essa proximidade tem sido relatada como importante para a saúde respiratória, uma vez que tem o potencial de influenciar a qualidade do ar em ambientes fechados (16). No entanto, nesta amostra não foi encontrada associação entre os episódios de sibilância e a proximidade de um local de poluição nem com o tipo de decoração utilizado no quarto.

A presença de bolores foi visível em 29,8\% dos quartos. Apesar da conhecida associação entre a presença de fungos e humidade com doenças respiratórias (10), a presença de bolores nos quartos desta amostra não foi associada a episódios de sibilância. No entanto, foi encontrada uma associação significativa entre a frequência de abertura da janela do quarto e a presença de bolores visíveis $\left(\chi^{2} 5,700 ; p=0,017\right)$. No modelo regressão logística, ajustado para o tamanho do quarto, humidade relativa e temperatura, verificou-se que a abertura da janela do quarto menos de uma vez por dia está associada à probabilidade de aparecerem bolores na parede do quarto [aOR 2,347 (IC 95\%: 1,047-5,263); ( $p=0,038)$ ]. Considerando que a presença de fungos é geralmente associada à doença respiratória, este resultado evidencia a importância de promover bons hábitos de higiene do ar interior através da sua renovação.

\section{Conclusão}

Este trabalho de investigação permitiu estudar a possível associação entre características de quartos de bebés e a ocorrência de episódios de sibilância, na região do Arco Ribeirinho. Apesar de examinar várias características do quarto, a área do quarto foi a única característica a mostrar um possível impacto no surgimento de episódios de sibilância: quartos maiores parecem impedir a ocorrência de mais episódios. Além disso, esta investigação contribui para destacar a importância da renovação do ar interior pelo menos uma vez por dia para evitar a formação de bolores. 
Nevertheless, more research should be promoted in this subject to address some of this study's limitations, namely a larger sample size and longitudinal measurements of indoor air quality parameters. This would allow the assessment of exposure to relevant indoor air pollutants on wheezing episodes.

\section{Acknowledgements}

The authors would like to thank all the participants, families and health professionals that allowed the data collection to take place, especially to Dr. Mário Durval - coordinator of the Public Health Unit Arnaldo Sampaio, from the Health Centres Cluster of Arco Ribeirinho.

\section{Conflicts of Interest}

The authors declare there is no financial or personal relationship that represents any potential conflict of interest.
Os trabalhos futuros sobre este assunto devem ter em conta algumas das limitações deste estudo, sobretudo, procurar um tamanho de amostra maior e medições longitudinais dos parâmetros de qualidade do ar interior. Isto permitiria descrever o efeito da exposição a poluentes relevantes do ar interior na ocorrência de episódios de sibilância na população em estudo.

\section{Agradecimentos}

Os autores gostariam de agradecer a todos os participantes do estudo, famílias e profissionais de saúde, que possibilitaram que a colheita de dados fosse executada, especialmente ao Dr. Mário Durval, coordenador da Unidade de Saúde Pública Arnaldo Sampaio do Agrupamento de Centros de Saúde do Arco Ribeirinho.

\section{Conflitos de interesse}

Os autores declaram que não existem relações pessoais ou financeiras que possam configurar uma situação de possível conflito de interesses.

\section{References/ Referências}

1. WHO. Global Plan of Action for Children 's Health and the Environment (2010-2015). Environment (2010).

2. Liu, L. et al. Global, regional, and national causes of under-5 mortality in 2000-15: an updated systematic analysis with implications for the Sustainable Development Goals. Lancet 388, 3027-3035 (2016).

3. Alvarez-Alvarez, I., Niu, H., Guillen-Grima, F. \& Aguinaga-Ontoso, I. Meta-analysis of prevalence of wheezing and recurrent wheezing in infants. Allergol. Immunopathol. (Madr). 46, 210-217 (2018).

4. Henry Gong, J. in Clin. Methods Hist. Phys. Lab. Exam. (eds. Kenneth Walker, H., W Dallas Hall, W. \& Willis Hurst, J.) (Butterworths, 1990).

5. Nurmatov, U. B., Tagiyeva, N., Semple, S., Devereux, G. \& Sheikh, A. Volatile organic compounds and risk of asthma and allergy: A systematic review. Eur. Respir. Rev. 24, 92-101 (2015).

6. Vanker, A., Gie, R. P. \& Zar, H. J. The association between environmental tobacco smoke exposure and childhood respiratory disease: a review. Expert Rev. Respir. Med. 11, 661-673 (2017).

7. Fuentes-Leonarte, V., Tenías, J. M. \& Ballester, F. Levels of pollutants in indoor air and respiratory health in preschool children: A systematic review. Pediatr. Pulmonol. 44, 231-43 (2009).

8. Emenius, G. et al. Building characteristics, indoor air quality and recurrent wheezing in very young children (BAMSE). Indoor Air 14, 34-42 (2004).

9. Franklin, P. J. Indoor air quality and respiratory health of children. Paediatr. Respir. Rev. 8, 281-286 (2007).

10. Simoni, M. Mould/dampness exposure at home is associated with respiratory disorders in Italian children and adolescents: the SIDRIA-2 Study. Occup. Environ. Med. 62, 616-622 (2005)

11. Landrigan, P. J. et al. The Lancet Commission on pollution and health. Lancet 391, 462-512 (2018).

12. Madureira, J., Paciência, I., Cavaleiro-Rufo, J. \& Fernandes, E. de O. Indoor air risk factors for schoolchildren's health in Portuguese homes: Results from a case-control survey. J. Toxicol. Environ. Heal. Part A 79, 938-953 (2016).

13. Rodrigues dos Santos, R., S. Fernandes, A. \& Castanheira, L. Development of a strategy to identify the characteristics of babie's rooms associated with volatile organic compounds and with the occurrence of wheezing. J. Biomed. Biopharm. Res. 14, 16-22 (2017).

14. Hulin, M., Caillaud, D. \& Annesi-Maesano, I. Indoor air pollution and childhood asthma: variations between urban and rural areas. Indoor Air 20 , 502-514 (2010).

15. Marfortt, D. A. et al. Differences between preschoolers with asthma and allergies in urban and rural environments. J. Asthma 55, 470-476 (2018)

16. Martins, P. C. et al. Airways changes related to air pollution exposure in wheezing children. Eur. Respir. J. 39, $246-253$ (2012). 